\title{
Reclaiming Root and Reframing History: Diasporic Consciousness in Michael Ondaatje's Running in the Family
}

\author{
Pabitra Bharali ${ }^{1}$, Dr. Bishnu Charan Dash ${ }^{2}$ \\ ${ }^{I}$ (Assistant Professor, Department of English, Digboi College, Digboi, Assam, India.) \\ ${ }^{2}$ (Associate Professor, Department of English, Assam University, Diphu Campus, Assam, India.)
}

\begin{abstract}
Reclamation of root in the original homeland and culture is integral to diasporic consciousness. Diasporas reclaim original identity through 'material' and 'cultural' links. On the one hand, they take up activities of 'maintenance and restoration' of the homeland as agents of development; on the other hand, psychically through memory, vision and myth and linguistically through historical research and literary production, they continue to have attachment to the homeland. The Sri Lankan-Canadian diasporic writer Michael Ondaatje holds a complex cultural position since he considers himself as a 'mongrel of place, race, culture and genres'. In his fictional memoir 'Running in the Family', his diasporic consciousness is depicted in the very act of reconstruction of family history. His memoir can be viewed as his attempt to come to terms with a past that is both personal and collective. He reframes his family 'history', and his historiography involves looking back at the three centuries old history and creative reworking of the changes over the times. This paper is an attempt to explore Ondaatje's diasporic consciousness as depicted in his reconstruction of family history in his memoir 'Running in the Family.
\end{abstract}

Keywords - Diasporic consciousness, family history, reclamation, root, Running in the Family

\section{INTRODUCTION}

Reclamation of root in the original homeland and culture is integral to diasporic consciousness. After the dislocation of the diasporic person from his/her land of origin, his/her identity is largely threatened in the host land. James Clifford assertively terms it as positive consciousness (311). By positive consciousness, Clifford tends to mean that the diaspora develops a strong sense of attachment to his/her native land and culture and that dislocation and experience of homelessness and rootlessness ignite an irresistible sense of nostalgia in the mind of the diaspora for the lost paradise. At the same time, diasporas reclaim original identity through 'material' and 'cultural' links. While the former signifies diaspora's revisits to the homeland and his/her contribution to its development, the latter stands for his/her mythic desire, memory and recollection, respect for and inculcation of native culture, language and literature even in the hostile foreign situations. In this context, Safran highlights the activities of 'maintenance and restoration' of the homeland by the diasporas (83). Similarly, while analyzing diasporas' contribution to developmental activities of the homeland, Cohen terms the diasporas as 'agents of development' (168). Revisits to homeland, homeland researches, reconstruction of homeland and involvement in homeland development activities are all that testify the diasporic reclamation of home in terms of material links. The cultural links of diasporas basically point to their psychic and linguistic connections. In fact, no diaspora can be free from their thoughts of homeland and native culture even though they may not continue to have any material links. In this connection William Safran observes that diasporic persons are characterized by their 'memory, vision and myth' about original homeland' (83) which justifies their cultural links. Avtar Brah's observation of homeland as a 'mythic place of desire' (192) vindicates the fact that diasporas, being unable to erase their memory of home, try to reclaim the 'root'. In much the same way, Rushdie's observation that 'the past is home'(9) points to diasporic attempt of reclamation and re-rooting. On the other hand, Clifford correlates diasporic identity with historical heritage (311).

Language is a significant way of reclaiming root. Acculturation of native language and use of homeland literary 'modes' point to diasporas' attachment to the 'root'. Diasporas may revive native language and literature in an attempt to remain connected to the original 'home'. Use of indigenous ethnic names, special words of homeland language(s) and appropriation of native literary practices are various dynamics of linguistic reclamation of root. In this connection, Vijay Mishra considers the very act of writing about homeland as a signifier of diasporic attachment to home culture. In his analysis of the diasporic writer V. S. Naipaul, he explains Naipaul's reclamation of root through 'memorial reconstructions' (familiar temporariness 193) i.e. construction of texts. In the backdrop of this theorization, an attempt has been made here to explore Ondaatje's diasporic consciousness as depicted in his reconstruction of family history in his memoir Running in the Family (1982). 


\section{ANALYSIS}

As a diasporic writer, Michael Ondaatje deserves special attention because of the many sided dualities associated with him - his blood, birth, sojourn and adoption. The Dutch Burgher ancestry, Ceylonese (Sri Lankan) nativity, western education and adoption of Canadian citizenship coupled with his deep sense of attachment to the country of birth make Ondaatje's cultural position somewhat complex. He holds a hybrid cultural position and it is signified by his own statement: "I am a mongrel of place. Of race. Of cultures. Of many genres." (Mc Crum). Ondaatje's own view of himself as a Sri Lankan as well as a Canadian is a pointer to the oscillation and double consciousness of the diasporic writer. The memoir Running in the Family brings to the fore this aspect of diasporic sensibility. In Running in the Family Ondaatje's diasporic consciousness is depicted in the very reconstruction of family history. As a diaspora Ondaatje, with his deep sense 'homeland orientation' (Brubaker 5) attempts to reconstruct the disjointed stories about his family and provide a coherent structure to his lineage. He is painfully conscious of the fact that he is a remnant of earlier generations that has been affected by various upheavals in course of time. He states:

During certain hours, at certain years in our lives, we see ourselves as remnants from the earlier generations that were destroyed. So our job becomes to keep peace with the enemy camps, eliminate the chaos at the end of Jacobean tragedies and with 'the mercy of distance' write histories. (201).

The above lines signify Ondaatje's deep sense of loss he has inherited from the family lineage. His persistent sense of crisis of identity brought about by the dissolutions his family provides him with three alternatives. He has either to 'keep pace with the enemy camps', be complacent and digest all sorts of humiliation or 'eliminate the chaos' in tragic encounter. As a third alternative, he can represent his experiences in 'histories'. Ondaatje chooses the third alternative and becomes the family historian. With his incessant attempt to create a niche for himself in Sri Lanka, he turns up the historian of the native land as well.

Ondaatje chronicles in Running in the Family his revisits to Ceylon (Sri Lanka) twenty-five years after his dispersion from the country to England and then to Canada. The motives behind his revisits were to recapture the world of his parents, the Ceylon of his early childhood, of the early decades of the century. At the surface an autobiographical work, it is far from being a straightforward life story. Himself a displaced person, Ondaatje displaces his genre and builds up his memoir with unstructured and randomly placed vignettes of varied lengths while flavouring it with poetry and photographs of Ceylon and the family. The work is replete with the stories and first-person voices of people other than the narrator. Moreover, there are also sudden shifts from the narrator's first to third person narration. At the 'Acknowledgements' he observes that 'a literary work is a communal act" (231) and warns the reader against reading the narrative as a standard autobiography: "I must confess that the book is not a history but a portrait or 'gesture'... (232).

Ondaatje's sense of loss is the core dynamic for the writing of this family history. He projects the losses experienced by his family throughout times. In the chapter entitled 'Historical Relations', Ondaatje explains the gap created between the Ceylonese community and the Europeans:

Everyone was vaguely related and had Sinhalese, Tamil, Dutch, British and Burgher blood in them going back many generations. There was a large social gap between this circle and the Europeans and English who were never part of the Ceylonese community. The English were seen as transients, snobs and racists, and were quite separate from those who intermarried and who lived here permanently" (31-32).

Though by implication the Burghers were closer to the land than the British, they were placed in near liminal space. Commenting on the predicament of the Ondaatjes Ernest MacIntire says that they had to suffer since they were marginalised when Ceylon was given the legality of independence. (315). Ondaatje's Burgher blood distances him from Ceylon and he experiences acute crisis of identity. Ondaatje projects his crisis of identity highlighting his distance from the father. With his dispersion in the childhood from Ceylon, he became physically distanced from his father. Added to that, he could not see his 'oneness' with him. Ondaatje now desires to understand the story of his father and his past implies that he has experienced a sort of dislocation from his father's care. Since he left Sri Lanka when he was only eleven, the memory of his father is not vibrant and as such memory of his father is like an empty space in his heart that haunted him throughout his life. He says that he did not know what his father felt of 'love, passion, duty' (201). He further adds: "My loss was that I never spoke to him as an adult (201). Towards the end, he makes a very significant comment that he could not "fully understand" (228) his father. His father was separated from them until he died (191). The distance of Ondaatje from his father thus stands for his dislocation as well as his personal identity crisis. With this experience of dislocation, he attempts to gather information and clues to his past. In fact, the narrative begins with Ondaatje's central quest to understand his father, Mervyn Ondaatje. It is soon discovered that the depiction of his father comes as a link to the construction of his own identity, his ancestry and his native country as well. Ondaatje's biographer Ed Jewinski's observation on Running in the Family is really relevant here:

Running in the Family is to be read as the record of the narrator's quest to find the roots of his own imagination in the details of his birth, his family, his inheritance. After all, the book was written at a time when Ondaatje, like his own father before him, was experiencing the powerful desires, moods, and tensions that 
would separate him from his wife and children. (115). The above quotation strongly indicates that Ondaatje's own sense of crisis at the impending dislocation of his family makes him realize the traumatic shock his father might have experienced at dissolution of his family in the past. With utmost respect and sympathy for the father, he desires reconciliation with him. But given the fact that his father is no more in the physical world, Ondaatje attempts to recover his identity through reconciliation with his father in an 'imaginative encounter' (Jewinski 116). Ondaatje feels that the refusal of a role in history signifies the loss of identity, and hence his incessant attempt is to reclaim his identity by creating a niche for himself in the native land. In his search for roots, he unearths his origin and recreates his family history:

"My own ancestor arriv(ed) in 1600, a doctor who cured the residing governor's daughter with a strange herb and was rewarded with land, a foreign wife, and a new name which was Dutch spelling of his own. Ondaatje.... And when his Dutch wife died, marr(ied) a Sinhalese woman, having nine children, and remain(ed). Here." (60). The name (Ondaatje), hardly recognizable as Tamil or Sinhalese, with minor changes, means 'to become one'. (Kanaganayakam: 35 ).

Ondaatje is obsessively concerned how to probe and resolve the duality associated with his family name. Following the introduction of Sinhala as the official language and Sinhala and Tamil as the languages of instruction, gradual disillusionment set in among the Burghers during late 1950s and early 1960s. Michael who had already left for the West was tormented with dream and nightmare for the native land and he felt he 'was already running' (6). In fact, 'runnings' have deep and multiple connotations in Ondaatje's use. At the sametime, it stands for a sense of belonging ('running to'), anxiety to belong ('running from'), and an awareness of the history and its historiography. Understanding these 'runnings' and situating himself in it is deeply problematic particularly for the dual associations he maintains.

Ondaatje's memoir captures the dilemma of the diasporic individual oscillating between feelings of belonging and not-belonging. In the spirit of Salman Rushdie's notion of the diaspora i.e., 'straddling two cultures', Ondaatje writes: "We own the country we grow up in, or we are aliens and invaders ... (80). The leap from one imagination to the other can hardly be made. Ondaatje of course runs to Sri Lanka: "I was running to Asia and everything would change ...I would be travelling back to the family I had grown from ... (22). The map of Ceylon showing some of the places in Ondaatje's plan of trip is graphed with this: "During quiet afternoons I spread maps onto the floor and searched out possible routes to Ceylon" (p. 22). But Ondaatje finds that the island of Ceylon which has been subjected to "the theories of sextant" (p. 63) for centuries, now exerts a challenge to Western cartography. In the chapter entitled "Tabula Asiae," Ondaatje enumerates the different historical names given to Sri Lanka over the centuries ( Serendip, Ratnadipa, Taprobane, Zeloan, Zeilan, Seyllan, Ceilon and Ceylon) and the various shapes accorded to the island. Ondaatje's narrative tries to reconstruct the 'fluid' map of his homeland. Ondaatje creates contingent maps of his island. Instead of evoking empirical elements of the landscape, Ondaatje recalls stories about his father and other family members. The fragmentary quality of the narrative reflects the fragmented yet distinct geographical landscape that constitutes home for Ondaatje.

Towards the end, Ondaatje's impressions of Ceylon differs and Ceylon become juxtaposed with Canada:

"Now, and here, Canadian February, I write this in the kitchen and play that section of cassette to hear not just peacocks but all the noises of the night behind them-inaudible then because they were always there like breath. In this silent room (with its own unheard hum of fridge, fluorescent light) there are these frogs loud as river, grunting, the whistle of other birds brash and sleepy" (144).

The two separate places are suddenly superimposed on one another. Ondaatje's construction of history of Ceylon is subconsciously affected by his dual consciousness or the fragmented soul.

Written from a diasporic background, Running in the Family depicts the disruptions, fractures and omissions that characterise diasporic history. For the other natives Ondaatje's Burgher ancestry represents "the residual vestiges of colonial domination" (Kanaganayakam 1992: 34). Nonetheless, Ondaatje states that Burghers, unlike Europeans, were natives of the island. In the narrative, Ondaatje presents his embeddedness in a community with Ceylon as native land. Running in the Family seems to demonstrate that history is never merely a neutral recital of facts. And as such, Ondaatje recreates family history through myths and memories. $\mathrm{He}$ asserts that "if anything," of his parents' generation was kept alive it is through "this recording by exaggeration" (186). Myth is added to stories, as for instance, the case/death of Lalla, Ondaatje's maternal grandmother, might die of alcohol poisoning, but is stated to be carried away by the flood waters. Notably, the manner in which the author weaves together memories in his text attests to their malleability. Ondaatje frames his history not with dry facts but with the flavours of a creative mind.

Diasporic identity implies multiplicity as well as fluidity, and hence its representation is constantly destabilised. Ondaatje in Running in the Family destabilises the representation of self and communal identities. In an attempt to retrieve self and communal identities, Ondaatje employs contemporary strategies of representation that undermine conventional notions of teleological history. He constructs a sense of self through imagination and myth. Ondaatje and his family are depicted as dwellers of the 'in-between' space having 
fragmented identities and experiencing overlay of cultures. Ondaatje in the memoir elucidates the ambiguities associated with the identity of the diasporic individual. The dichotomy of the sense of belonging to both the native and the foreign land is very candidly expressed by the writer's identification of himself as the foreigner and the prodigal: "I am the foreigner. I am the prodigal who hates the foreigner" (78). As the prodigal he is constantly drawn to the words "sea," and "harbour," and is in love with the song "Harbour Lights." (141). He is aware that in the blistering heat during New Year festivities, people enjoy themselves climbing grease poles, throwing water on passing cyclists. But for his family, the experience was very different because they "drove towards lowland heat, growing belligerent and yelling at each other to shut up ..."(80). It is so because of the fact that the cultural allegiance of his community lies in far off cultures. Again, it is because of this that the author wholeheartedly agrees when his daughter says at Kuttapitiya, the estate famous for its gardens, "if we lived here it would be perfect" (157). "

Ondaatje had the awareness of closeness and distance. The author's own view on the writing of the work speaks for his oscillation: "I just had to say to myself that I thought I was writing the book with enough love, that if it was me it would be ok" (Solecki 331). His inevitable identities remain, that he is Burgher, Sri Lankan and Canadian. At this point, it will be worthwhile to see his identity in relation to his father since his journey to Sri Lanka was mainly a quest for his father, an attempt to exorcise feelings of guilt and betrayal. There is 'no attempt to sentimentalise or universalize the experience between the father and the son' (Kanaganayakam: 40). The father is a dipsomaniac, a bully, a spendthrift. By heart he is a colonial officer for which even in his drunkenness and moments of hallucination, he cannot but be respectful to British officers. Ondaatje recreates this history in an unflattering way, i.e. he refers to Sir John Kotelawala's mention of his father not by name but as "that chap." (173). Of course, in the latter part of the work, the lonely, depressed and lovable man's feelings are expressed. He just wished that he could kiss [them] all once again (198). This is certainly significant in the assertion of root by Ondaatje as a diasporic individual.

\section{CONCLUSION}

Ondaatje's fictional autobiography can be viewed as his attempt to come to terms with a past that is both personal and collective. He reframes his 'history', and his historiography involves looking back at the three centuries old history and creative reworking of the changes over the times. Of course, Ondaatje is almost silent over the political upheavals in Sri Lanka in the postcolonial period. His geographic distance turns out to be his disengagement and disinterestedness in the national history of the time. Ondaatje's historiography, from this perspective interrogates the very claim he attempts to assert - his rootedness. Of course his concern for reconstruction of family history, renewed sense of attachment to his father, his visit and revisit of Sri Lanka in the accompaniment of his family members are clear pointers of his diasporic sensibility of reclamation of root. Ondaatje's diasporic imagination is satisfactorily at work because he assertively maintains that memory can help organize family history. To conclude, Running in the Family, therefore, becomes more relevant as a diasporic text wherein the diasporic writer has successfully attempted to rewrite his family history with emphasis on displacement and dislocation.

\section{REFERENCES}

[1] Clifford, James.”Diasporas". Cultural Anthropology. vol. 9 no 3 (Aug 1994). 302-338.

[2] Safran, William. "Diasporas in Modern societies: Myths of Homeland and Return". Diaspora: A Journal of Transnational Studies. Vol I, no. I (Spring 1991). 83-99.

[3] Cohen, Robin. Global Diasporas: An Introduction. $2^{\text {nd }}$ Edition. 2008. London and New York: Routledge. 2010.

[4] Brah, Avtar. Cartographies of Diaspora: Contesting Identities. London and New York: Routledge. 1997.

[5] Mishra, Vijay. "The Familiar Narrative- Naipaul, Diaspora and the literary Imagination: a personal narrative" The South Asian Diaspora-Transnational Networks And Changing Identities. eds. Rajesh Rai and Peter Reeves. London and New York, Routledge. (2009). 193-208.

[6] Ondaatje, Michael. Running in the Family. 1982. London/Berlin/New York: Bloomsbury. 2009.

[7] McCrum, Robert. "Michael Ondaatje: The Divided Man.” The Observer. Sunday 28 August, 2011.

[8] Brubaker,Roger' The 'diaspora' diaspora Rogers Ethnic and Racial Studies Vol. 28 No. 1 January 2005 pp. 1 19

[9] MacIntire, Ernest. "Outside of Time: Running in the Family" Spider Blues: Essays on Michael Ondaatje. ed. Sam Solecki. (Montreal: Vehicule, 1985): 315-319.

[10] Jewinski, Ed. Michael Ondaatje: Express Yourself Beautifully. Toronto: ECW, 1994.

[11] Kanaganayakam, Chelva. “A Trick with a Glass: Michael Ondaatje’s South Asian Connection”. Canadian Literature. 132 (Spring 1992) 33-42.

[12] Rushdie, Salman. Imaginary Homelands: Essays and Criticism: 1981-1991.1991. London: Vintage Books. 2010.

[13] Solecki, Sam. "An Interview with Michael Ondaatje." Spider Blues: Essays on Michael Ondaatje. ed. Sam Solecki. (Montreal: Vehicule, 1985): 321-332. 